\title{
AN EVALUATION OF THE EFFECT OF BIRD STRIKES ON FLIGHT SAFETY OPERATIONS AT INTERNATIONAL AIRPORT
}

\author{
Jaiye Jehoshaphat Dukiya ${ }^{1}$, Vimal Gahlot ${ }^{2}$ \\ ${ }^{1}$ Federal University of Technology, Department of Transport Management Technology, Minna, Nigeria \\ ${ }^{2}$ Public Works Department, Government of Rajasthan, Jaipur, Rajasthan, India
}

Received 24 July 2012; accepted 25 October 2012

\begin{abstract}
As man continues to encroach on the natural habitat of the arboreal (birds and other wildlife), problems like aircraft-bird strikes continues to aggravate as air traffic volume increases. This study focused on the Aminu Kano International Airport in Nigeria due to importance of its geographical location and the air traffic flow. The analysis result reveals that 12 bird species were involved in 44 strikes at the airport between the year 2001-2010 and mostly during the rainy seasons. The airport during the same period recorded 55,205 aircraft movement that carried 3,551,587 passengers. Distribution of these strikes by phase indicates that $32 \%$ occurred on approach, $25 \%$ on landing roll, $20 \%$ on takeoff, $4.5 \%$ on descend, $4.5 \%$ during climb while $14 \%$ at other phases. Using the International Bird Strike Committee strike rate (per 10,000 flights), the computed strike rate for this airport is 7.97 per 10,000 flights. It is therefore recommended that "Bird Strike Avoidance Radar" equipment that will alert the control tower which will in turn alert the pilot of the presence of birds along his way be installed in major airports in the country.
\end{abstract}

Keywords: airport management, aviation safety, bird strike, land use.

\section{Introduction}

Conflicts between birds and aircraft have increased dramatically in the resent years because the world has become a global village through technological advancement in communication and significant improvement in aircraft design (Faster and Quieter). Globally, the bird strikes have resulted in loss of more than 219 people and 200 aircraft since 1988 (ICAO, 2006). Several factors contribute to this increasing threat. Many populations of bird species commonly involved in strikes have increased markedly in the last few decades. In addition, air traffic has also increased substantially since 1980 . Collisions with birds and other wildlife have negatively impacted the airline industry, and ultimately the flying public. In addition to the economic losses, some collisions have resulted in loss of human life. Although the economic costs of bird strikes are extreme, the cost in human lives lost when aircraft crash as a result of strikes best illustrates the need for management of the wildlife strike problem.

Historically, the first powered flight by the Wright Brothers occurred in December 1903, and the wildlife strike problem began shortly thereafter. The first reported bird strike occurred on 7 September 1905 as recorded by Oliver Wright in his diary, when his aircraft hit a red-winged blackbird as he flew over a cornfield near Dayton Ohio. On 3 April 1912

${ }^{2}$ Corresponding author: vgahlot@rediffmail.com 
Calbraith Rodgers, the first person to fly across the continental USA, was also the first to die as a result of bird strike when his aircraft struck a gull along the coast of Southern California (Cleary and Dolbeer, 2005). Since those first bird strikes, aircraft designs and performance have changed radically, and bird populations and air traffic have also increased (Dolbeer and Seubert, 2009). As a result, at least 122 civil aircraft have been destroyed and over 255 civilian lives have been lost worldwide due to bird strikes from 1960 to 2004. During this same period, bird strikes have resulted in at least 333 military aircraft destroyed and over 150 military personnel killed (Shobakin, 2009).

For example, 56 reports of significant damage to aircraft taking off or arriving at Sacramento International Airport, which is located in popular destination for birds, near a river in California's Central Valley. Of those reports, 36 - or $64 \%$ of the total - occurred above 500 feet (Cleary and Dolbeer, 2005). In Nigeria, Dana Air Mc Donnel Douglas Aircraft (MD83), on April 19, lost one of its engines on takeoff due to bird strike at the Murtala Muhammed Airport, Ikeja, and Lagos. The incident forced the pilot to initiate an air return, as balls of smoke tailed the affected left engine which was later followed with a loud bang that caused panic within the airport environment. Also another Abuja bound MD83 aircraft with 97 passengers on board took off at the domestic runway of the Murtala Muhammed Airport, when flocks of egret birds got ingested into the left engine of the aircraft. The pilot initiated an airreturn back to the airport, with Fire Service officials of the Federal Airports Authority of Nigeria (FAAN), providing fire cover for safe landing of the aircraft and eventual evacuation of the 97 passengers. Permanent Secretary, Ministry of Aviation Ms Anne Ene
Ita said the frequency of bird strikes in West Africa is worrisome. According to the airline's Chairman, Joseph Arumemi-Ikhide, between 2011 and 2012 alone, Arik Air has suffered 43 bird strikes and lost about N3.2 billion naira (US \$20.67 million). Bird strike has been the cause of many accidents in air travel and costs the airlines of over N20 billion annually.

The majority (90\%) of bird collisions occur near or on airports according to ICAO during takeoff, landing and associated phases. According to the FAA wildlife hazard management manual for 2005 (Cleary and Dolbeer, 2005), less than $8 \%$ of strikes occur above $900 \mathrm{~m}(2,953 \mathrm{ft})$ and $61 \%$ at less than $30 \mathrm{~m}(100 \mathrm{ft})$. According to Lateef Lawal (Nigerian Aviation News), in Nigeria, bird strike has remained dangerous as any other place in the world, but what is frightening is that not so much is being done to mitigate it.

Jet engines are particularly vulnerable during the takeoff phase when the engine is turning at a very high speed and the plane is at a low altitude where birds are more commonly found. The force of the impact on an aircraft depends on the weight of the animal and the speed difference and direction at the impact. The energy of the impact increases with the square of the speed difference. Hence, a low-speed impact of a small bird on a car windshield causes relatively little damage. High speed impacts, as with jet aircraft, can cause considerable damage and even catastrophic failure to the vehicle. Damaged jet engine after bird strike can damage vehicle components, or injure passengers. Flocks of birds are very dangerous and can lead to multiple strikes, and damage. Depending on the damage, bird strikes at low altitudes or during takeoff and landing often cannot recover in time, and thus crash. 
Apart from the fact that bird strikes have been gulping hundreds of millions of dollars from the debt-ridden domestic airline operators, one worrisome fact is that recent global research has revealed that bird strike is now responsible for up to $45 \%$ of air crashes. Studies reveals that bird strike happens at critical point of flight (take off and landing) and that birds now fly on the same flight level with airplanes; the bird strike incident that happened over Hudson River in New York occurred when the aircraft had just taken off. The plane took off and ran into flights path of a flock of geese and the plane had that can be referred to as 'double injection'. This made the two plane's engines to suddenly stop working. The aircraft had to look for a place to land because it lacked engine power to fly back to the airport.

The onset of the jet age revolutionized air travel, but magnified the bird strike problem, modern jet aircraft are faster and relatively quiet, and their engine fan blades are often more vulnerable than propellers to wildlife-strike damage. When turbinepowered aircraft collide with birds, serious structural damage and engine failure can occur.

The aim of this study is to assess the environmental management of Mallam Aminu Kano International Airport (MAKIA) in relation to the frequency of bird strike in Nigeria aviation industry with a view of encouraging the adoption of best practices in the furtherance of aviation safety crusade in the country through the following objectives:

- Examine the ecological setting and management of the airport in the area.

- Examine the rate of bird strike occurrence and the species involved.

- To rank the identified problem birds according to the Aviation Risk Safety Value (ARSV) and evolve remedial measures that are cost-effective in the country.

\section{The Study Area}

Mallam Aminu Kano International Airport (MAKIA) is located in Kano city in the savanna region of northern Nigeria (Fig. 1). It is the
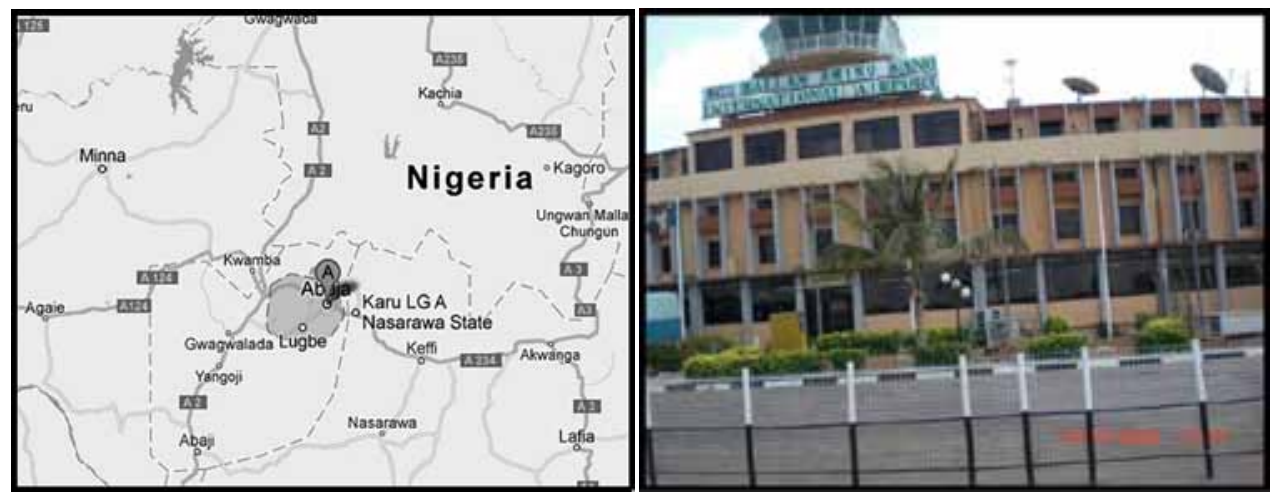

Fig. 1.

Location and Front View of Mallam Aminu Kano International Airport Kano

Source: Google Map 
oldest airport in Nigeria with operations starting in 1936. Prior to this date, Kano also recorded the first ever aviation activity in Nigeria when a Royal Air Force aircraft operated by the British colonialist landed at a polo ground in the city in 1925. This historic reconnaissance flight during the First World War later developed into regular military flights. The infrastructural development of the airport actually started in 1930s thus making the city of Kano into a veritable hub rivaled only by Khartoum in the African continent. Owing to the historical status of Kano Airport, the Nigerian airspace which comprises both the continental and oceanic territorial airspace is named the Kano Flight Information Region (FIR). Kano hosts KLM the longest-serving foreign airline in Nigeria which started operations since 1947. In January 1957, the airport was opened for 24 hours operations with Comet 15, DC-6 and Argon flights becoming the first to use the main runway. Currently the bulk of international flights cater for the large Lebanese community in Kano and Muslim pilgrimages to Mecca. The airport is served by two runways: Runway 06/24 and Runway 05/23 mainly used for civilian and military flights respectively. The runways together with associated taxiways, links and apron accommodates both small, medium and large aircraft such as B747, A310, DC-10, Lj45, C550, HS125, Fokker100, D225, DASH-8, TB-9, C201, etc. The airport has cargo balloon sheds operated by Nigerian Aviation Handling Company (NAHCO) and Sky Power Handling Company Limited (SAHCOL). Each uses sophisticated cargo handling equipment and fuel farms such as Mobil, Conoil, National and joint aviation facility supply hydrant fuel for passenger and cargo aircraft.

\section{Literature Review}

Bird strikes in Nigeria and world-wide appear to be increasing over the last few years. Aircraft collisions with birds and other wildlife cost the airline industry, and ultimately the flying public, approximately US $\$ 2$ billion, annually (USA, 2009). The greatest loss of life directly attributed to bird strike occurred on $4^{\text {th }}$ October 1960 when a Lockheed L-188 Electra flew through a flock of starlings during take-off damaging all four engines. The aircraft crashed shortly after take-off into Boston Harbour USA, killing 62 out of 72 passengers. On the average, aircraft crashes every eighteen months as a result of a bird strike related incident (Thomas, 1990).

In the United States, bird strike continues to be a safety threat to air travel. On January $15^{\text {th }} 2009$ the geese knocked out both engines of a US Airways jet over New York's Hudson River and its emergency landing on the river drew the attention of the aviation industry in the United States. The industry recognized that birds are a significant threat and more needs to be done to mitigate the risk. In fact, the US government estimates about 10,000 reported bird strikes in 2009 - a $32 \%$ increase over the 7,600 reported strikes in 2008.

According to FAA's data, airplanes struck birds 46 times at Philadelphia International Airport in the first seven months of 2009 during takeoff or landing, or en route, and of the 46, only one was considered "substantial". In that March $21^{\text {st }}$ incident, an Air Wisconsin Airlines pilot reported smelling smoke in the cabin, possibly due to a bird sucked into Engine 2. The flight returned to the airport, where damage caused by a goose or duck was repaired at a cost of $\$ 88,300$. Engines on the most popular models of large jets, such as the Boeing 737 and the Airbus A320, are not certified to withstand an impact with birds larger than four pounds (Fig. 2). 
Woronecki et al. (1992) conducted safety efficacy and clinical trials required to register alpha-chloralose (A-C) for capturing nuisance waterfowl and pigeons with the U.S. Food and Drug Administration (FDA) during 1990 and 1991, and it was found out that the Most Effective Dose (MED) to be 30 and $60 \mathrm{mg}$ of A-C/kg of body weight for capturing waterfowl and pigeons, respectively. Afterwards, 11 field trials were conducted in 4 states, capturing 587 waterfowl and 1,370 pigeons with $8 \%$ mortality for ducks, $0 \%$ for geese, and $6 \%$ for pigeons. The New Animal Drug Application was submitted to FDA in October 1991 and received registration in 1992 for use of A-C by Wildlife Service's biologists.

Barras et al. (2002) reviewed published studies to summarize findings on habitat management techniques that have shown potential for wildlife strike reduction. Habitat components that may attract wildlife to airports include food, cover, water, and loafing areas. Although maintaining tall herbaceous vegetation on airfields may reduce the attractiveness of loafing and feeding sites for some species of birds such as gulls, this strategy may also increase cover and food resources for other hazardous species. Thus, optimum vegetation height management strategies require further research and may be site-specific.

Barras et al. (2000) evaluated bird and small mammal use of two mowed ( 15 to $25 \mathrm{~cm}$ height) and two unmowed vegetation plots ( 40 to 88 ha) at John F. Kennedy International Airport (JFKIA), New York, in 1998 to 1999 to determine which management strategy would best reduce wildlife use of the airport. They counted more birds per 5-minute observation period in unmowed plots than mowed plots in both 1998 (9.0 versus 7.9) and 1999 (11.7 versus 8.6). Maximum vegetation height was greater $(P<0.05)$ for unmowed areas than mowed areas after mowing commenced in 1998 and 1999 for each two-week monitoring period. In 1998 to 1999 , vegetation density was also higher $(P<0.05)$ for unmowed plots for 13 of 14 sampling periods. The species composition of vegetation differed $\left(\mathrm{X}^{2}=20.54, \mathrm{df}=3\right.$,

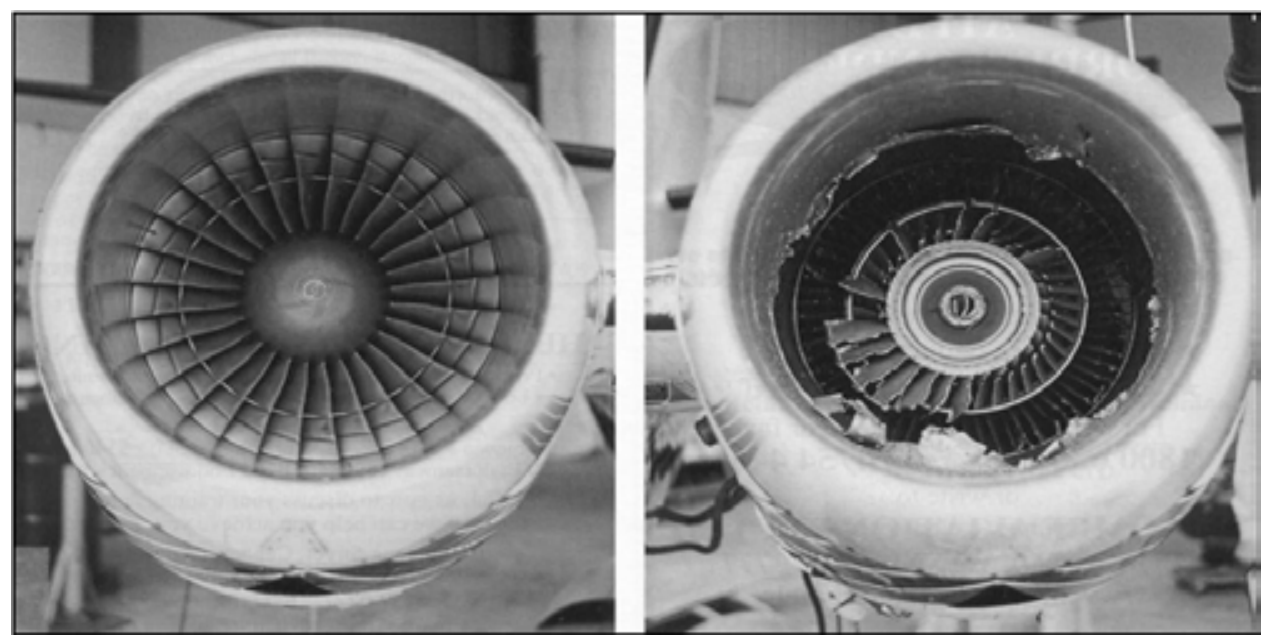

Fig. 2.

Jet Engine Blade Damaged by Bird Strike 
$\mathrm{P}<0.01$ ) among mowed and unmowed plots. Mowed plots contained a higher percentage of grasses ( $81 \%$ versus $68 \%$ ), and a lower percentage of forbs (16\% versus $25 \%$ ) and woody plants ( $1 \%$ versus $4 \%$ ) than unmowed plots. Vegetation was generally sparse in both unmowed and mowed plots, a consequence of the poor, sandy soils on much of the airport. 33 small mammals were captured from three species in unmowed plots and 12 individuals of one species in mowed plots in 1999. Small mammal populations increased seasonally in unmowed plots, but remained constant in mowed plots over the same time period. They recommended that JFKIA switch from the unmowed vegetation management regime in place since 1986 to a regime of maintaining vegetation mowed at 15 to $25 \mathrm{~cm}$ height. This management strategy should reduce bird and small mammal use of grassland areas at JFKIA. They concluded by recommending further research to examine the use of alternative vegetation types to improve ground cover and vegetation density at JFKIA while minimizing attraction to wildlife.

Anghileri et al. (2009) studied the feasibility of different numerical models (Eulerian and ALE model, NM model, SPH model), as a tool to investigate the consequences of a bird strike and penetration inside the airframe of a turbofan intake were considered. Advantages and disadvantages of these models have been discussed. Eventually, a model particularly suitable to analyse such a complicated event, namely the SPH model, has been identified. Indeed, this model is deemed reliable and feasible to be used to accurately analyse the dynamics of the event and, hence, to be used as part of a methodology to design highefficiency bird-proof structures.

According to Beason and Begier (2006), assessing wildlife hazards to aviation in the airport environment is typically initiated by conducting a Wildlife Hazard Assessment (WHA). Ecological relationships between wildlife populations and habitat are usually discerned through observations during the course of one annual cycle. He opined that proximate hazards, on the airport, are well defined during the WHA process, off-airport features also can attract wildlife. Wildlife species can transit airport property travelling to and from habitat attractants. During a WHA, common wildlife sampling techniques are employed to determine species, their approximate numbers, and through association an index of potentially attractive habitat. Continuous observations could provide a more complete picture but would require greater sampling effort. Radar, he argued is a tool that has demonstrated efficacy to automatically monitor wildlife at greater distances than can be achieved through traditional techniques. Modern systems also have the ability to record a variety of spatial and temporal variables simultaneously and processed data streams can be further analyzed. In association with GIS software, these data can be queried to provide hazard and risk mapping on the airfield and in the approach/ departure corridors, as well as the air traffic pattern. The use of radar in combination with traditional wildlife observation techniques could significantly increase the amount of information available for analyses during a WHA.

In Kenya, Nasirwa (2001) observed that approximately $21 \%$ of all Kenya's bird species are migratory. The migrants include 171 Palaearctic, 55 Afro tropical and 4 Malagasy migrant species. Non-migrant species too are very mobile. The bulk of migratory birds visiting or passing through Kenya use the Rift Valley, coast, eastern bush lands, central and western grasslands as their flyway. About $46 \%$ of Kenya's migratory species are water birds. These migrate mainly along the Rift 
Valley and the coast. Over $70 \%$ of the water bird populations concentrate in the major Rift Valley lakes. These lakes are also on the flight path of most international airline routes to and from Nairobi. While en route, airplanes fly at higher altitudes than migrating birds.

In Nigeria, the airline operators are bleeding financially to fix damaged parts of aircraft due to bird strikes running into billions of dollars. In 2008, Arik Air, the largest domestic carrier, experienced over 34 incidents of bird strike attacks on its aircraft, costing the manager over N3.2 billion (US $\$ 20.67$ million) to fix its aircraft struck by birds. Another operator (Dana Air) lost over N270 million (US \$1.7 million) in 2010 due to the attack of birds on its aircraft. In fact, Harold Demuren, director general, Nigerian Civil Aviation Authority (NCAA), had in June 2010 lamented that bird strike incidents account for over $40 \%$ of all incidents that occur within the airports, adding that the Mallam Aminu Kano International Airport, Kano, is among the list of airports where aircraft engines and other parts had been badly damaged by such occurrence (Dumerun, 2010). Over 850 species of birds have been documented in the country which is associated to some particular environment (Shobakin, 2009).

Gustafson el al. (2003) reviewed the status of the avifauna in extreme NE Nigeria based on observations made from 1997 to 2000 . A total of 311 bird species were encountered, of which 105 were Palearctic migrants. Eight birds new to Nigeria were observed and several others new to the area were found to be more common than earlier thought. They compared their observations with the 1960s, when the area was intensively studied, and noted several sharp declines. Among such declines is the disappearance of colonies of herons, egrets and cormorants, which is related to the drought- induced reduction in the level of Lake Chad, its northern basin having virtually dried out since the late 1960s and been mostly transformed into dense bush or wooded savanna. However, they observed that a few semi-desert species have extended their range southward. Other declines, including bustard species and the disappearance of Ostriches Struthio Camelus and Black Crowned Crane Balearica Pavonina, are more likely due to the growing human population, with increased hunting, egg collecting, overgrazing and competition for water.

All vulture species have diminished considerably, most probably due to poisoning. They relied on Elgood et al. (1994) studies as the baseline for discussions of changes in distribution and abundance, summarizing knowledge up to about 1992 and depended upon the checklist for the Malamfatori area published by Hopson (1964) and Ash et al. (1967) to provide information from the 1960s, for compares with their data. This approach may be invaluable in identifying and documenting birds in Kano and its environs. They presented result in a systematic list (as indicated below) that summarizes observations for 165 species. A total number of species observed during the Lake Chad Bird Migration Project was 311, out of which 105 were palearctic migrants. At least 4 species occurred with both resident and Palearctic subspecies (Black Kite, Hoopoe, Rufous Scrub-Robin and Olivaceous Warbler).

\section{Methodology}

Questionnaire survey and field observation are the main instrument employed to source for primary data in this study. In this regard, two questionnaires were designed and administered to 11 different commercial flights that include; (Dana Air, Aric Air, KLM, IRS Air, Kabo Air, Aero Contractor, 
Quatari Airline, Virgin Nigeria, Hamsal Air, Egypt Air and Saudi Arabia Air) and neighboring communities around the airport. The questionnaire focused on the character of the birds, the environmental conditions and agricultural practices within a radius of $15 \mathrm{~km}$ from the airport that attracts birds to feed, nest, or roost at or within the vicinity of the airport environment. The villages covered for the study is as displayed in Table 1.

The aircraft model was also considered as it influences the level of vulnerability to birds strike. The aircraft models operating in this airport studied include: A330, CRJ900, B747, B757, B767, EMB145, B727, A310 and Fokker 100. These were assessed based on their frequent involvement in bird strike reported cases. A total number of 44 bird strikes were reported or confirmed during the period 2001-2010 as per the survey. As indicated in Fig. 3a, involvement of aircraft in bird strike shows gradual increase from two in 2001, 2002 and 2004 to three in 2004 whilst four, six, eight and ten were recorded for 2006, 2007, 2008 and 2010, respectively. Analysis of the bird strike records indicates that 39 of the 44 or $89 \%$ of the total strikes were reported by airlines alone.

Field observations were carried out around the two runways (06/24 and 05/23), the taxiway, apron as well as the approach and climb out area of the airport. Similarly, other areas of interest to this study particularly the airport environment including but not limited to the

\section{Table 1}

Sampled Villages and their Sample Size

\begin{tabular}{|c|c|c|c|}
\hline S/N & Village & Population & $\begin{array}{c}\text { Sample Size } \\
\text { (Number of Persons })\end{array}$ \\
\hline 1 & Jaba & 10000 & 60 \\
\hline 2 & Dan Rimi & 8000 & 50 \\
\hline 3 & Takole & 6500 & 40 \\
\hline 4 & Bukavu Barrack & 5000 & 30 \\
\hline 5 & Rimaye & 5000 & 30 \\
\hline 6 & FAAN Quarters & 4000 & 25 \\
\hline 7 & Takurza & 3000 & 20 \\
\hline 8 & NAF Base & 3000 & 20 \\
\hline 9 & Zango & 2500 & 15 \\
\hline 10 & Police Barrack & 2500 & 15 \\
\hline 11 & Kumantaka & 2300 & 15 \\
\hline 12 & NAF Medical Centre & 1000 & 5 \\
\hline 13 & Sabon Birni & 500 & 5 \\
\hline 14 & Kanyan Amana & 350 & 5 \\
\hline 15 & Rafin Mallam & 250 & 5 \\
\hline 16 & Alafa & 200 & $\mathbf{3 5 0}$ \\
\hline & Total & $\mathbf{5 4 1 0 0}$ & \\
\hline
\end{tabular}


airport perimeter fencing, water hydrant and refused dump sites were carefully monitored and observed in a slowly driven four wheel vehicle provided by the Bird/Wildlife Hazard Control Unit.

The breakdown of bird strike report by airline includes IRS Airline (28\%), KLM (23\%), Virgin Nigeria (13\%), Belview Air (5\%), Nigeria Airways (5\%), Saudia Arabian Airline (5\%), Dana Air (2.5\%), Arik Air (2.5\%), Kabo Air (2.5\%), Aero Contractors (2.5\%), Qatari Air (2.5\%), Hansal (2.5\%), Ethiopia
Airline (2.5\%) and Egypt Air (2.5\%) as shown in Fig. $3 b$, involvement of airlines in bird strike. IRS Airline which reported the highest percentage of bird strike also operates the highest frequencies of flights from MAKIA in recent times.

Secondary data were collected from the staffs of FAAN in Wild Life Hazard Control Unit, Environment and Airport Safety Management System Departments. Others include Airline Operational staff, Aviation Fire \& Rescue Services and Air Traffic Controllers and some

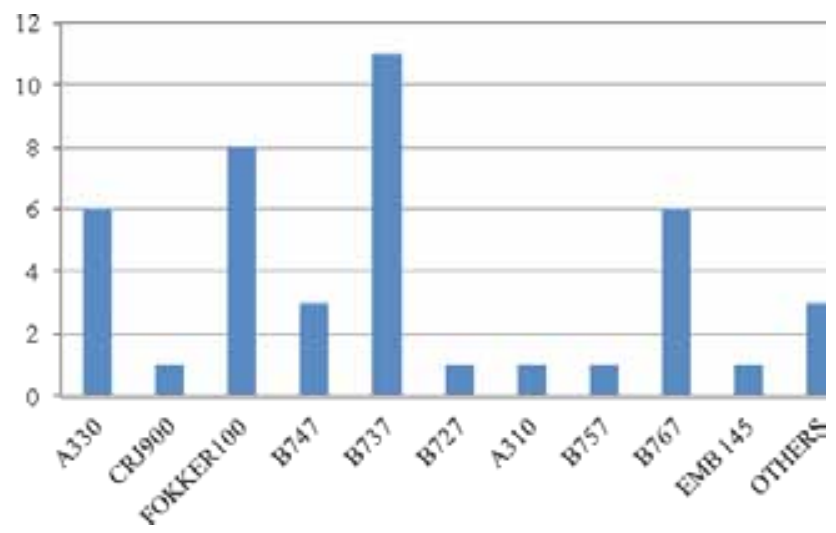

Fig. 3a.

Involvement of Aircraft in Bird Strike

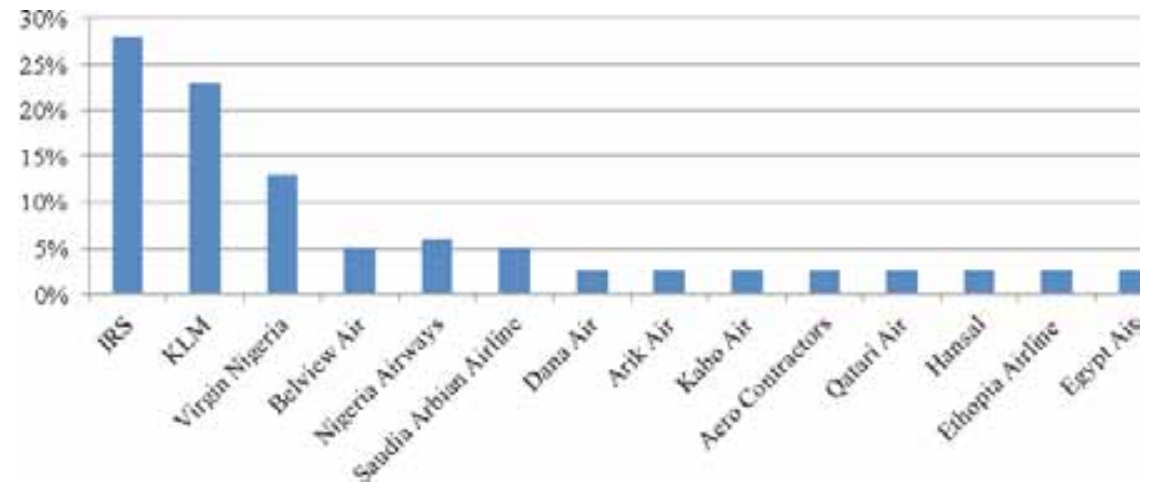

Fig. 3b.

Involvement of Airlines in Bird Strike 
members of the Airport Bird/Wildlife Hazard Control Committee. In addition two local bird 'experts' from the neighboring villages of Jaba and Fanisau were also interviewed particularly on the character, population, size, and behavior of local and migratory bird species. The summary of aircraft movement in MAKIA during 2001-2010 is presented in Table 2. The bird strike phenomenon is very peculiar in nature and varies with location and altitude as shown in Fig. 4a and Fig. 4b, which explains that maximum number of strikes occurs when aircraft is on approach and minimum while it is descend or climbing. It is clear from the study frequent bird strike occurs at moderate height, i.e. 150-250 ft.

\section{Aviation Safety Ranking Value (ASRV)}

The Aviation Safety Ranking Value (ASRV) postulated by IBSC (2002) was used to evaluate and rank the risk of bird strikes to particular specie. Aviation Safety Ranking Value separates birds in five levels according to the potential hazard to have collision with an aircraft:

- Level 1 - without significant relevance for air traffic safety;

- Level 2 - low potential danger;
- Level 3 - intermediate potential danger;

- Level 4 - high potential danger;

- Level 5 - very high potential danger.

These levels are evaluated based on size of each bird species (mainly weight), the social pattern and behavior of the species, and its movements (short and long distance) and the activities in the airport.

The study also use the Aviation Safety Risk Value (ASRV) in classifying birds in five levels that represent the potential danger that each of these birds poses to aviation based on the flight safety relevance of bird species (Morgenroth, 2003).

\section{Result and Discussion}

The field data collected shows that about 27 bird species were common in this part of the country as displayed in the Appendix 1.22 of these birds are residents while 5 are migrants. The character, behaviour, and size of these birds also differ from specie to specie. These birds are grouped as soaring birds, which caused bird hazard within the airport and outside at almost all flight phases of aircraft (Black Kite, Harriers, etc.).

Table 2

Summary of Aircraft Movement in Makia 2001-2010

\begin{tabular}{|c|c|c|c|c|c|c|}
\hline \multirow[t]{2}{*}{ Years } & \multicolumn{2}{|c|}{ Arrival Aircraft } & \multicolumn{2}{|c|}{ Departure Aircraft } & \multirow[t]{2}{*}{ Total } & Bird strike \\
\hline & Domestic & International & Domestic & International & & \multirow{12}{*}{$\begin{array}{c}\text { Total Bird } \\
\text { Strike in Yr. } \\
2001-2010 \\
=44 \\
\text { Total Flight = } \\
55205 \\
\text { Bird Strike } \\
\text { Rate per } \\
10000 \text { is } 7.97\end{array}$} \\
\hline 2001 & 1512 & 1218 & 1297 & 1056 & 5083 & \\
\hline 2002 & 1305 & 923 & 1308 & 966 & 4502 & \\
\hline 2003 & 1952 & 952 & 1901 & 974 & 5779 & \\
\hline 2004 & 2050 & 741 & 1970 & 822 & 5583 & \\
\hline 2005 & 1878 & 732 & 1536 & 851 & 4997 & \\
\hline 2006 & 2117 & 733 & 1941 & 915 & 5706 & \\
\hline 2007 & 2128 & 707 & 1909 & 929 & 5673 & \\
\hline 2008 & 2073 & 747 & 1875 & 938 & 5633 & \\
\hline 2009 & 2166 & 973 & 1994 & 983 & 6116 & \\
\hline 2010 & 2173 & 984 & 1989 & 987 & 6133 & \\
\hline Grand Total & \multicolumn{2}{|c|}{28,064} & \multicolumn{2}{|c|}{27,141} & 55,205 & \\
\hline
\end{tabular}




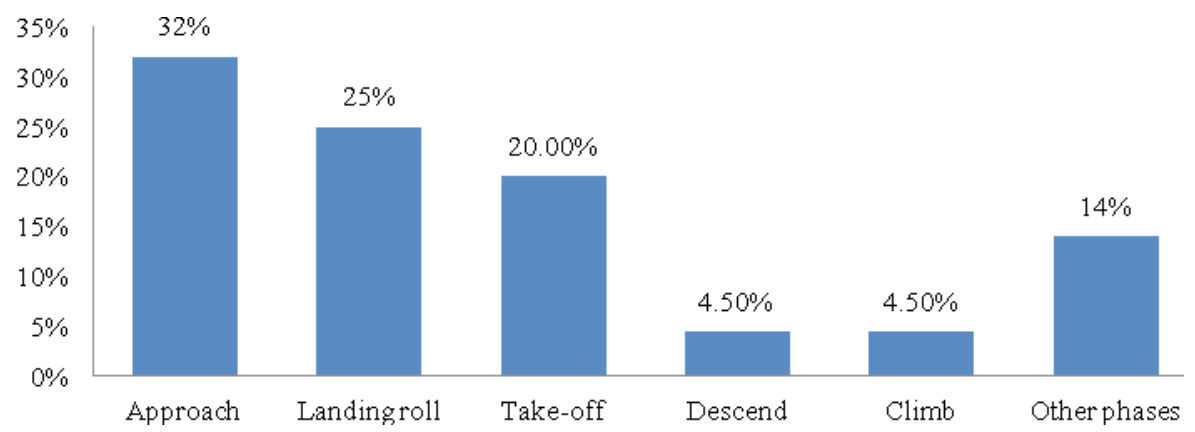

Fig. 4a.

Phases of Bird Strike on Airport

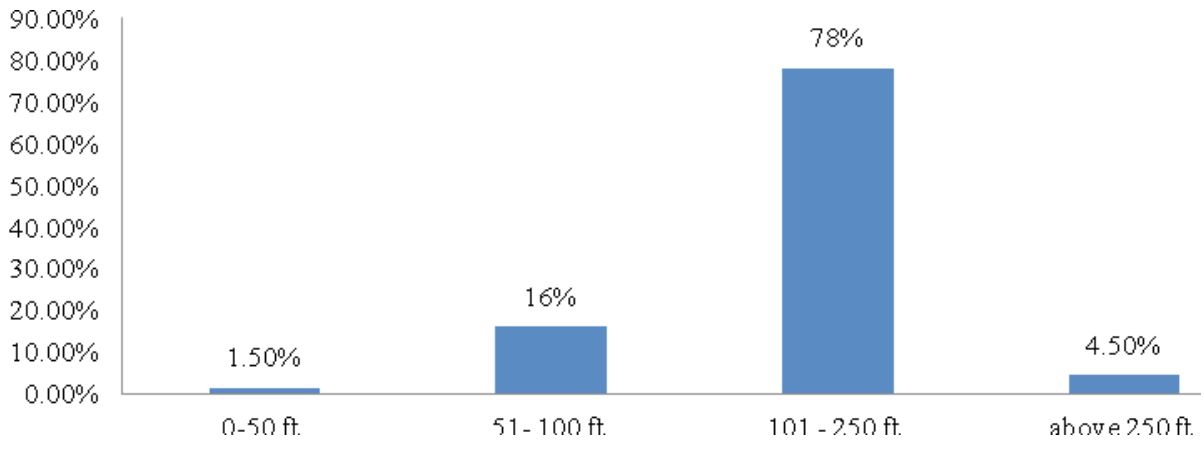

Fig. 4b.

Phases of Bird Strike on Airport

An analysis of bird strike records indicates that twelve bird species were involved in bird strikes from 2001-2010. The highest bird strikes of 9 was recorded for Lapwing, 5 for Bats, 4 for Kestrel while Back Kite and Cattle Egret were involved in 3 strikes each. Similarly, Owl and Kill bird were involved in 2 strikes each whilst one was recorded each for Eagle, Black Headed Heron, Marsh Harrier, Speckled Pigeon and Quela. Fig. 5 shows bird species involved in 2001-2010, while Fig. 6 displays bird strike occurrences by bird strike months 2001-2010.

\section{Airport Ecology and Habitat Management}

The birds which are found on and in vicinity of the airfield of Kano airport are generally present because the condition found at the airport suits their needs. The availability of food, water and shelter makes Mallam Aminu Kano International Airport attractive to birds. Birds fly into the airport in order to feed on insects, earthworm, mice, moles, spiders, weed seeds, snakes, lizards, other small birds, dead animals, assorted grain crops, human garbage and food wastes. 


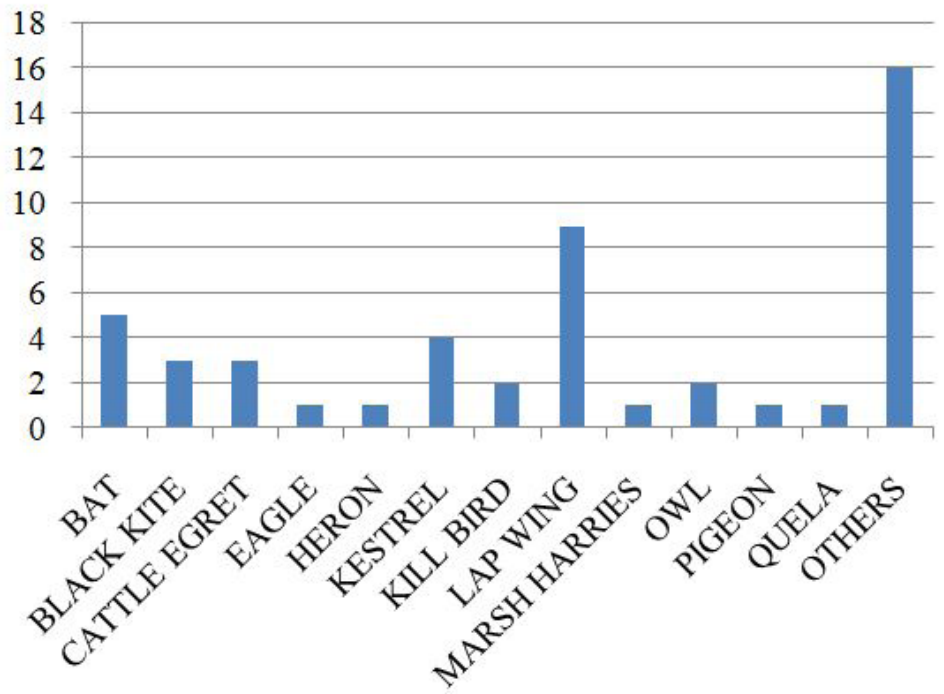

Fig. 5.

Bird Species Involved in 2001-2010

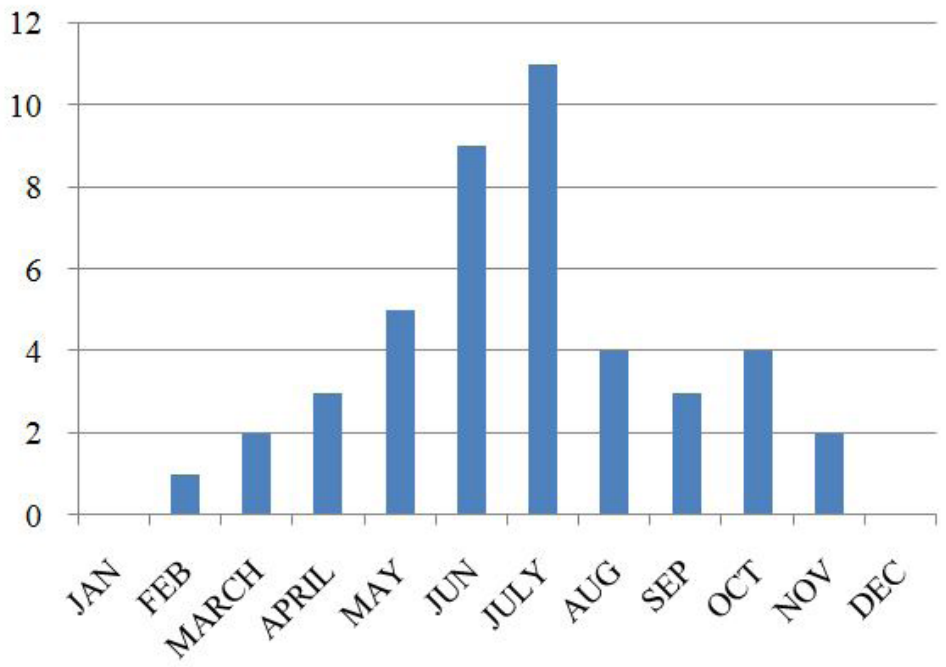

Fig. 6.

Bird Strike Occurrences by Bird Strike Months 2001-2010 
It is observed that grass is cut very short at the edge of runway $06 / 24$, exposing large population of insects most notably grasshoppers and centipedes that attracts cattle egrets. Large flocks of quelea have been observed during the rainy season. Pigeons and dove are common birds of this area.

There is a steady source of grain crop grown during the rainy season which supports these birds. Outside the airport and on the approach ends of both runway $06 / 24$ and $05 / 23$, fields are been cultivated to farm maize, millet and sorghum in places such as Bukava barrack, Jaba and Alafa villages as shown in Fig. 7 and Fig. 8.

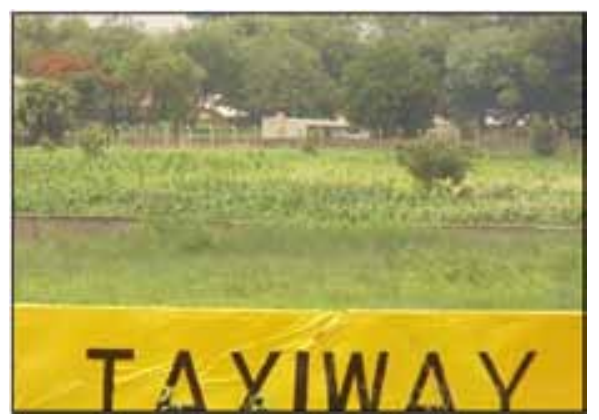

Fig. 7.

Maize Farmlands Across the Airport Perimeter Fence

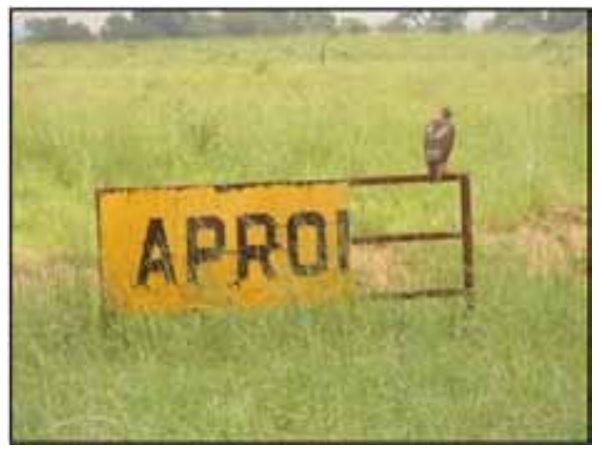

Fig. 8.

Black Kite Loafing on Airport Apron Stand
Garbage dumps also is just $15 \mathrm{~m}$ from the tarmac that is attracting black kite and other predatory birds as indicated in Fig. 9. It was also observed that garbage from restaurant, canteens and other eateries situated within the old terminal building across the international arrival and departure hall, cargo balloon shelter and customs office attracts numerous birds. Marsh harrier, Heron and other predatory birds have been sighted in the horizon above the city abattoir which is located about 3.5 $\mathrm{km}$ from the airport as shown in Fig. 10. The location of this abattoir is aligned to the extended centre line of runway 05 frequently used by the Nigerian Air Force aircraft.

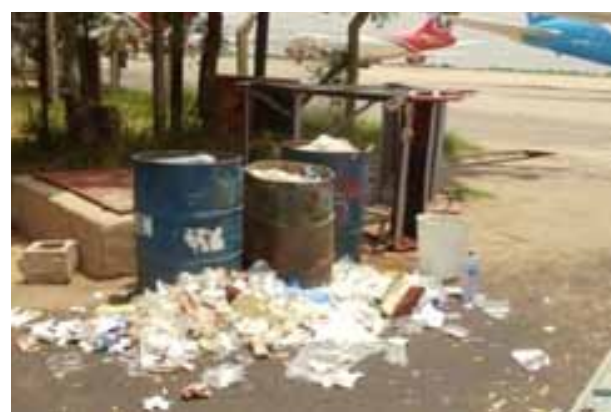

Fig. 9.

Waste Disposal in Drums Close to the Apron

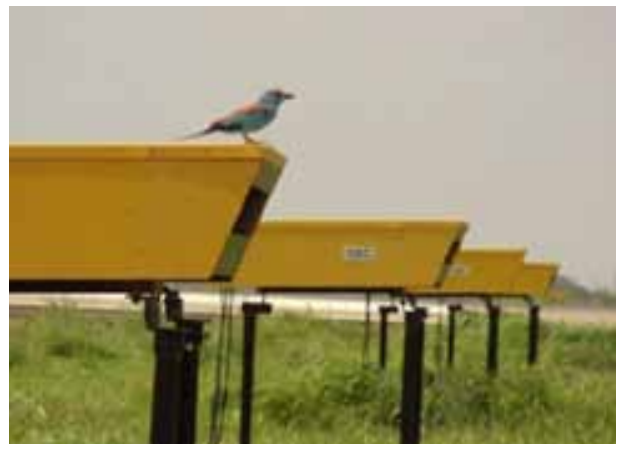

Fig. 10.

Abyssinian Roller Loafing Aeronautical Light Panel 
Kano airport can be described as an "oasis" in the middle of an unsuitable habitant for birds. The airport is attractive because it is different from its surroundings. It provides shelter, food, and water and green vegetation through the year which is scarce in the surrounding country side.

\section{Birds Hazard Ranking}

Bird's species are categorized based on their size (mainly weight), the behavior, and their movement (short and long distance) and the activities in the airport. Based on the internationally accepted approximation criterion of size classification, birds are classified small $(5-25 \mathrm{~cm})$, medium (25.1$39.9 \mathrm{~cm}$ ) and large $(40-80 \mathrm{~cm})$ (Morgenroth, 2003). The derived aviation safety risk value obtained from the study area is given in Table 3.

\section{Effect of Bird Strike on Flight Operations}

The effect of bird strikes on aircraft operations is measured mainly in monetary terms. It is difficult to obtain an accurate estimate of the cost of bird strikes for airline and aerodrome operations, let alone the cost of bird hazard management. However, recent reports show that, world-wide, bird

Table 3

Hazard Ranking - Aviation Safety Risk Value (ASRV)

\begin{tabular}{|c|c|c|c|c|c|c|c|}
\hline $\mathbf{S} / \mathbf{N}$ & Specie Name & Scientific Name & Body Size & Status & Range & Weight & Ranking \\
\hline 1 & Abdim Storck & Ciconia abdimi & $\mathrm{L}$ & $\mathrm{Mi}$ & $\mathrm{h}, \mathrm{s}$ & $1 \mathrm{~kg}$ & 2 \\
\hline 2 & Abyssinian roller & Coracias abyssinicus & $\mathrm{M}$ & $\mathrm{Mi}$ & $\mathrm{f}, \mathrm{r}, \mathrm{s}$ & $110 \mathrm{~g}$ & 2 \\
\hline 3 & Bat hawk & Macheiramphus alcinus & $\mathrm{L}$ & $\mathrm{R}$ & $\mathrm{H}$ & $1.2 \mathrm{~kg}$ & 3 \\
\hline 4 & Black headed heron & Ardea melanocephala & $\mathrm{L}$ & $\mathrm{R}$ & $\mathrm{h}, \mathrm{r}, \mathrm{s}$ & $1.2 \mathrm{~kg}$ & 4 \\
\hline 5 & Black kite & Milvus migrans & $\mathrm{M}$ & Mi & $\mathrm{h}, \mathrm{r}, \mathrm{s}$ & $600 \mathrm{~g}$ & 5 \\
\hline 6 & Buffalo weaver & Bubalornis albirostris & $S$ & $\mathrm{R}$ & $\mathrm{f}, \mathrm{c}, \mathrm{s}$ & $75 \mathrm{~g}$ & 2 \\
\hline 7 & Cattle egret & Bubulus ibis & $\mathrm{M}$ & $\mathrm{R}$ & f, s, & $400 \mathrm{~g}$ & 4 \\
\hline 8 & Common bulbul & Pycnonotus barbatus & $S$ & $\mathrm{R}$ & $\mathrm{f}, \mathrm{s}$ & $60 \mathrm{~g}$ & 1 \\
\hline 9 & Crested lark & Galerida cristata & $S$ & $\mathrm{R}$ & $\mathrm{f}, \mathrm{s}$ & $95 \mathrm{~g}$ & 1 \\
\hline 10 & Dove & Streptopelia senegalensis & $\mathrm{M}$ & $\mathrm{R}$ & $\mathrm{f}, \mathrm{s}$, & $400 \mathrm{~g}$ & 2 \\
\hline 11 & Eagle & Hieraatus spilogaster & $\mathrm{L}$ & $\mathrm{R}$ & $\mathrm{h}, \mathrm{r}, \mathrm{s}$ & $1.5 \mathrm{~kg}$ & 3 \\
\hline 12 & Finches & Serinus leucopygius & $S$ & $\mathrm{R}$ & $\mathrm{f}, \mathrm{fc}$ & $80 \mathrm{~g}$ & 3 \\
\hline 13 & Francolin & Francolinus swainsonii & $\mathrm{M}$ & $\mathrm{R}$ & & $300 \mathrm{~g}$ & 2 \\
\hline 14 & Kestrel & Falco naumanni & $\mathrm{M}$ & $\mathrm{R}$ & $\mathrm{h}, \mathrm{c}, \mathrm{r}, \mathrm{s}$ & $650 \mathrm{~g}$ & 5 \\
\hline 15 & Lapwing & Vanellus tectus & $\mathrm{M}$ & $\mathrm{R}$ & $\mathrm{f}, \mathrm{fc}$ & $450 \mathrm{~g}$ & 5 \\
\hline 16 & Little swift & Apus affinis & $S$ & $\mathrm{R}$ & $\mathrm{f}, \mathrm{fc}$ & $60 \mathrm{~g}$ & 1 \\
\hline 17 & Marsh harrier & Circus ranivorus & $\mathrm{L}$ & $\mathrm{R}$ & $h, r, s$, & $900 \mathrm{~g}$ & 2 \\
\hline 18 & Night jar & Macrodipteryx longipennis & $\mathrm{M}$ & $\mathrm{Mi}$ & $\mathrm{f}, \mathrm{s}$, & $450 \mathrm{~g}$ & 1 \\
\hline 19 & Northern red bishop & Euplectes franciscanus & $S$ & $\mathrm{R}$ & f, $s$, & $155 \mathrm{~g}$ & 1 \\
\hline 20 & Owl & Tyto alba & $\mathrm{M}$ & $\mathrm{R}$ & $\mathrm{h}, \mathrm{r}, \mathrm{s}$, & $550 \mathrm{~g}$ & 4 \\
\hline 21 & Pied crow & Corvus albus & $\mathrm{L}$ & $\mathrm{R}$ & $\mathrm{h}, \mathrm{r}, \mathrm{fc}$ & $850 \mathrm{~g}$ & 3 \\
\hline 22 & Quela & Quela quela & $S$ & $\mathrm{Mi}$ & $\mathrm{f}, \mathrm{fc}$ & $155 \mathrm{~g}$ & 2 \\
\hline 23 & Red billed hornbill & Tockus erythrorhynchus & $\mathrm{M}$ & $\mathrm{R}$ & $\mathrm{f}, \mathrm{s}$, & $600 \mathrm{~g}$ & 1 \\
\hline 24 & Senegal coucol & Centropus seneglensis & $\mathrm{L}$ & $\mathrm{R}$ & f, s, & $350 \mathrm{~g}$ & 2 \\
\hline 25 & Speckled pigeon & Columbo guinea & $\mathrm{L}$ & $\mathrm{R}$ & $\mathrm{f}, \mathrm{fc}_{\mathrm{c}}$ & $500 \mathrm{~g}$ & 3 \\
\hline 26 & Starlings & Lamprotormis candatus & $\mathrm{M}$ & $\mathrm{R}$ & $\mathrm{f}, \mathrm{fc}_{\mathrm{c}}$ & $400 \mathrm{~g}$ & 2 \\
\hline 27 & Village weaver & Ploceus cucullatus & $\mathrm{S}$ & $\mathrm{R}$ & $\mathrm{f}, \mathrm{fc}$ & $200 \mathrm{~g}$ & 3 \\
\hline
\end{tabular}

Key: $\mathrm{L}=$ Large, $\mathrm{M}=$ Medium, $\mathrm{S}=$ Small, $\mathrm{R}=$ Resident, $\mathrm{Mi}=$ Migrant, $\mathrm{f}=$ Field bird, $\mathrm{fc}=$ Flocking, $\mathrm{h}=$ High/Soaring, $\mathrm{r}=\mathrm{Raptor}$, $\mathrm{s}=$ Scarce, $\mathrm{c}=$ Common 
strike-related costs amount to $\$ 1.2$ billion annually (Dolbeer and Subert, 2009). The Federal Airport Authority of Nigeria estimated that the combined cost of aircraft inspections, repairs, cleaning and delays related to bird strike events was 20 billion naira (US $\$ 0.126$ billion). This included flight delays, crew alterations, rescheduling flights and accommodation, and injuries. The chairman of Arik Air, the largest domestic carrier, Sir Joseph Arumemi - Ikhide stated that in 2009, the airline had suffered 43 bird strikes and lost over 3.2 million naira (US $\$ 20.23$ thousand) to fix its aircraft struck by birds (Osa-Okunbor, 2010). Similarly, Jacky Hathiramani, Managing Director, Dana Airlines reported losing 270 million naira (US $\$ 1.71$ million) as a result of bird strike to one of its aircraft in 2010. The chairman, Airline Operators of Nigeria (AON), Mr Stave Mahowu was quoted stating that the airlines were bleeding financially to fix damaged blades of aircraft due to bird strikes running into billions of dollars (Adekola, 2010). The Director-General, Nigeria Civil Aviation Authority (NCAA), was also quoted saying that bird strikes incident account for over 40 percent of all incidents that occur within the airports (Adekola, 2010). In fact, industry experts estimate that a single engine blade cost about US $\$ 36,000$.

A single damage to the engine fan of a DC-10 at MAKIA cost between US \$236.8 and US $\$ 294$ in 1984 for the cost of repairs only and this is about US \$119.76 and US \$148.72 in the year 2012 going by the present exchange rate of NGN 158.180 naira to US \$1. Closely related to this are other considerations such as delays, rescheduling or cancellation of flight, passenger accommodation, feeding, and compensation, etc. The combined cost of a single damaging bird strike is therefore much higher.

\section{Conclusion and Recommendation}

A significant number of a variety of bird species is observed in the vicinity of Kano airport. The propensity of these birds to collide with aircraft is real and this is a menace to the aviation industry.

Nigeria, as a signatory to the Convention on International Civil Aviation Organization (ICAO), Chicago 1944, is obligated to implement the provisions specified in Annex 14 of the Convention. It is apparent that bird strike reporting is highly dependent on the willingness of pilots, airline officials, and the level of adherence to professional ethics.

Bird hazard on the airport has both safety and economic implication. It behoove the Federal Ministry of Aviation (FMA) to collaborate with parastatal under its supervision to create the much needed synergy to promote safety through technological adoption and rigorous awareness campaign in order to reduce or effectively manage the menace of bird strikes at the airport. The following recommendations are therefore given as a solution to the menace.

- What we should have done in Nigeria is to put in place equipment that will alert the control tower which will in turn alert the pilot of the presence of birds along his way. This equipment is now being installed in major airports in the United States and other countries. It is called Bird Strike Avoidance Radar.

- There are actually several systems to be combined to conquer the bird strike menace, namely scaring the birds from the flight area with Durban dog; falcons; with these, they go about chasing these birds.

- Disposal of garbage by the catering services at the airport should be well managed to discourage scavenging birds from dumps. 
- Bird Strike Avoidance Radar' equipment that will alert the control tower which will in turn alert the pilot of the presence of birds along his way be installed in major airports in the country.

- Since modern aircraft are no longer noisy to scare away most birds, bird repellents should be built into aircraft and airports.

- The Bird/Wildlife Hazard Control
(B/WHC) unit of all the nations' international airports should be well trained and equipped with current equipments that can repel birds around the ports.

- Farming activities around the airport should be kept away at a reasonable distance since they act as feeding place for birds.

\section{Appendix 1}

Common Bird Species Observed at Makia

\begin{tabular}{|c|c|c|c|c|c|}
\hline S/N & Specie & Scientific Name & Body Size & Status Category & Range Category \\
\hline 1 & Abdim storck & Ciconia abdimi & $75-8 \mathrm{~km}$ & $\mathrm{M}$ & $\mathrm{R}$ \\
\hline 2 & Abyssinian roller & Coracias abyssinicus & $28-30 \mathrm{~cm}$ & $\mathrm{M}$ & $\mathrm{C}$ \\
\hline 3 & Bat hawk & Macheiramphus alcinus & $41-45 \mathrm{~cm}$ & $\mathrm{R}$ & $\mathrm{U}$ \\
\hline 4 & Black headed heron & Ardea melanocephala & $92-96 \mathrm{~cm}$ & $\mathrm{R}$ & $\mathrm{U}$ \\
\hline 5 & Black kite & Milvus migrans & $50-60 \mathrm{~cm}$ & $\mathrm{Mp}$ & $\mathrm{C}$ \\
\hline 6 & Buffalo weaver & Bubalornis albirostris & $22-24 \mathrm{~cm}$ & $\mathrm{R}$ & $\mathrm{C}$ \\
\hline 7 & Cattle egret & Bubulus ibis & $48-56 \mathrm{~cm}$ & $\mathrm{R}$ & $\mathrm{C}$ \\
\hline 8 & Common BulBul & Pycnonotus barbatus & $18-20 \mathrm{~cm}$ & $\mathrm{R}$ & $\mathrm{C}$ \\
\hline 9 & Crested lark & Galerida cristata & $15-17 \mathrm{~cm}$ & $\mathrm{R}$ & $\mathrm{C}$ \\
\hline 10 & Dove & Streptopelis senegalensis & $23-25$ & $\mathrm{R}$ & $\mathrm{C}$ \\
\hline 11 & Eagle & Hieraatus spilogaster & $60-70 \mathrm{~cm}$ & $\mathrm{R}$ & $\mathrm{C}$ \\
\hline 12 & Finches & Serinus leucopygius & $10-11.5$ & $\mathrm{R}$ & $\mathrm{R}$ \\
\hline 13 & Francolin & Francolinusswainsonii & $30-35 \mathrm{~cm}$ & $\mathrm{R}$ & $\mathrm{C}$ \\
\hline 14 & Kestrel & Falco naumanni & $30-38 \mathrm{~cm}$ & $\mathrm{R}$ & $\mathrm{C}$ \\
\hline 15 & Lapwing & Vanellus tectus & $21-25 \mathrm{~cm}$ & $\mathrm{R}$ & $\mathrm{C}$ \\
\hline 16 & Little swift & Apus affinis & $12-13.5 \mathrm{~cm}$ & $\mathrm{R}$ & $\mathrm{C}$ \\
\hline 17 & Marsh harrier & Circus ranivorus & $44-50 \mathrm{~cm}$ & $\mathrm{R}$ & $\mathrm{U}$ \\
\hline 18 & Night jar & Macrodipteryx longipennis & $21-22 \mathrm{~cm}$ & $\mathrm{M}$ & $\mathrm{C}, \mathrm{f}$, \\
\hline 19 & Northern red bishop & Euplectes franciscanus & $11-12 \mathrm{~cm}$ & $\mathrm{R}$ & $\mathrm{C}, \mathrm{f}$, \\
\hline 20 & Owl & Tyto alba & $33-36 \mathrm{~cm}$ & $\mathrm{R}$ & $\mathrm{C}$ \\
\hline 21 & Pied crow & Corvus albus & $46-50 \mathrm{~cm}$ & $\mathrm{R}$ & $\mathrm{C}$ \\
\hline 22 & Quela & Quela quela & $11-13 \mathrm{~cm}$ & $\mathrm{M}$ & $\mathrm{C}$ \\
\hline 23 & Red billed hornill & Tockus erythrorhynchus & $40-48 \mathrm{~cm}$ & $\mathrm{R}$ & $\mathrm{C}, \mathrm{f}$ \\
\hline 24 & Senegal coucol & Centropus seneglensis & $36-40 \mathrm{~cm}$ & $\mathrm{R}$ & $\mathrm{C}$ \\
\hline 25 & Speckled pigeon & Columba guinea & $35-40 \mathrm{~cm}$ & $\mathrm{R}$ & $\mathrm{C}$ \\
\hline 26 & Starlings & Lamprotormis caudatus & $20-51 \mathrm{~cm}$ & $\mathrm{R}$ & $\mathrm{C}, \mathrm{f}$ \\
\hline 27 & Village weaver & Ploceus cucullatus & $15-17.5 \mathrm{~cm}$ & $\mathrm{R}$ & $\mathrm{C}$ \\
\hline
\end{tabular}

Key: $\mathrm{R}=$ Resident, $\mathrm{M}=$ Migrant, $\mathrm{Mp}=$ Migrant Palearctic, $\mathrm{C}=$ Common, $\mathrm{U}=$ Uncommon, fairly common 


\section{References}

Adekola, S. 2010. Menace of the bird strikes and its economic pain. Available from Internet: <http://www. tribune.com.ng >.

Anghileri, M.; Castelletti, L.M.L.; Molinelli, D.; Motta, F. 2009. A Strategy to Design Bird-proof Spinners. Available from Internet: <www.dynalook.com/european-conf2009/H-I-02.pdf>.

Ash, J.S.; Ferguson-Lees, I.J.; Fry, C.H. 1967. B.O.U. Expedition to Lake Chad, Northern Nigeria, 109(1967): 478-486.

Barras, S.C.; Carrara, M.S.; Dolbeer, R.A.; Chipman, R.B.; Bernhardt, G.E. 2000. Bird and small mammal use of mowed and unmoved vegetation at John F. Kennedy International Airport, 1998 to 1999. In Proceedings of Vertebrate Pest Conference, (19): 31-36.

Barras, S.C.; Seamans, C.T. 2002. Habitat management approaches for reducing wildlife use of airfields. In Proceedings of Vertebrate Pest Conference, (20): 309-315.

Beason, R.C.; Begier, M.J. 2006. The use of Radar to augment visual observations in wildlife hazard assessments. In Proceedings of the 8th Bird Strike Committee USA/Canada Annual Meeting, St. Louis, Missouri, USA. 9 p.

Cleary, E.C.; Dolbeer, R.A. 2005. Wildlife Hazard Management at Airport: A Manual of Airport Personnel, Second Edition. 1-135.

Dolbeer, R.A.; Seubert, J.L. 2009. Canada goose populations and strikes with civil aircraft, 1990-2008: challenging trends for aviation industry. Washington, DC: US Department of Agriculture, Wildlife Services, Airport Wildlife Hazards Program. Available from Internet: <http://si-pddr.si.edu/jspui/bitstream/10088/7872/1/ vz_Marra_Dove_etal_proof_Frontiers_in_Ecology.pdf $>$.

Dumerun, H.O. 2010. Air Safety in Nigeria. Available from Internet: <http://en.wikipedia.org/wiki/Harold_Demuren>.
Elgood, J.H.; Heigham, J.B.; Moore, A.M.; Nason, A.M.; Sharland, R.E.; Skinner, N.J. 1994. The Birds of Nigeria - an annotated check-list. British Ornithologists Union, Check-List No. 4 (Second Edition). The Natural History Museum, Tring. Available from Internet: <http://www.birdlife.org/datazone/speciesfactsheet. php?id=7154>

Gustafsson, R.; Hjort, C.; Ottosson, U.; Hall, P. 2003. Birds of Lake Chad and in the Sahel of North Eastern Nigeria, 1997-2000, The Lake Chad Bird Migration Project, Ottenby Bird Observatory, Degerhamn, Sweden.

Hopson, C. 1964. Vietnam Air Losses, USAF, USN, USMC, Fixed-Wing Aircraft Losses in Southeast Asia 1961-1973, North Branch, Minnesota: Specialty Press, ISBN 1-85780-115-6.

International Bird Strike Committee (IBSC). 2002. Best Practices Manual An Aviation Guide To The Management OfWildlife Hazards. Available from Internet: $<$ http://www.int-birdstrike.org/referenceInformation cfm?ref=Amsterdam $>$.

International Civil Aviation Organization (ICAO). 2006. Regional Seminar on Wildlife Hazard Reduction, Bangkok, Thailand. Available from Internet: <http:// www.bangkok.icao.int/news/ICAO_APAC-RegionalReport.pdf $>$.

Morgenroth, C. 2003. Development of an Index for Calculating the Flight Safety relevance of Bird Species for an Assessment of the Bird Strike Hazard at Airports, Bird and Aviation, 23(2): 1-7.

Nasirwa, O. 2001. Bird Migration and Bird Strike situation in Kenya, National Museum of Kenya. In Proceedings of a workshop held at the National Museums, Nairobi, Kenya. Available from Internet: <http://www.birds.org.il/SIP STORAGE/files/5/1505.pdf $>$.

Osa-Okunbor, K. 2010. Bird strike: Domestic airlines count losses. Available from Internet: <http://www. thenationonlineng.net>. 
Shobakin, H.O. 2009. Bird Prevention: Control techniques adopted by FAAN. A paper presented at the Ramp Safety Event, Mallam Aminu Kano International Airport, Kano, Nigeria. 23-35 p.

Thomas, S. 1990. Bird Hazard Management at Manchester Airport, Manchester Airport Plc Report. 101-116.

USA. 2009. Managing wildlife hazards to aircraft, $A$ USA presentation to ICAO North American, Central American and Caribbean Office (NACC), $10^{\text {th }}$ meeting of Directors of Civil Aviation of the Central Caribbean (C/CAR/DCA/10), Grand Cayman, Cayman Island.

Woronecki, P.P.; Dolbeer, R.A.; Seamans, T.W.; Lance, W.R. 1992. Alpha-chloralose efficacy in capturing nuisance waterfowl and pigeons and current status of FDA registration. In Proceedings of the Vertebrate Pest Conference, (15): 72-78.

\section{PROCENA UTICAJA UDARA PTICA NA BEZBEDNOST LETENJA NA MEĐUNARODNOM AERODROMU}

\section{Jaiye Jehoshaphat Dukiya, Vimal Gahlot}

Sažetak: Ugrožena staništa mnogih vrsta ptica i drugih životinjskih vrsta, dovela su do pojave njihovog naseljavanja u okolini aerodroma što izaziva probleme poput udara ptica u vazduhoplov, sa tendencijom porasta u skladu sa povećanjem obima vazdušnog saobraćaja. Prikazana studija se odnosi na međunarodni aerodrom Aminu Kano u Nigeriji zbog njegovog značaja u pogledu geografskog položaja i protoka vazdušnog saobraćaja. Rezultati istraživanja su pokazali da je 12 vrsta ptica učestvovalo u 44 zabeležena udara ptica na aerodromu u periodu između 2001. i 2010. godine i to najviše tokom kišne sezone. Na aerodromu je tokom ovog perioda realizovano 55.205 operacija pri čemu je prevezeno 3.551.587 putnika. Raspodela udara ptica prema fazama leta ukazuje na to da se $32 \%$ udara desilo u prilazu, $25 \%$ u toku sletanja, $20 \%$ tokom poletanja, $4,5 \%$ u poniranju, a $14 \%$ u drugim fazama leta. Prema podacima međunarodne organizacije International Bird Strike Committee, dobijena je stopa udara ptica za ovaj aerodrom koja iznosi 7,97 udara na 10.000 letova. Stoga se na svim glavnim aerodromima u zemlji preporučuje uvođenje radara za praćenje ptica kako bi se preventivno, kroz komunikaciju kontrolni toranj - pilot, smanjila mogućnost udara ptica u vazduhoplov.

Ključne reči: upravljanje aerodromom, bezbednost vazdušnog saobraćaja, udar ptica, prostorno planiranje. 